tions, 1912-15, of the Southern Manitoba Mounds Region. By Katherine H. Capes. Pp. iii +178 (19 plates). Ottawa: Queen's Printer, 1963). This investigation utilizes the extensive field notes of Nickerson to produce a full report of his work and to show the relationship of the burial mounds of the area to those of other regions. On the basis of form, burial site and grave goods, and on distribution, the author suggests that the mounds form a north-western periphery to a great burial mound complex on the Northern Plains, evolving perhaps from Middle Woodland antecedents, and introduced into southern Manitoba by the Assiniboine.

A recent number of Études Anthropologiques, Musée National du Canada (No. 6, March 1964), describes the excavation of an Early Woodland site near the north bank of the St. Lawrence River (Le Gisement de Batiscan. Notes sur des vestiges laissés par une peuplade de culture Sylvicole inférieure dans la valle du Saint-Laurient. Par L'Abbe Rene Levesque, F. Fitz Osborne et J. V. Wright. Pp. 49 (5 plates). Ottawa: Queen's Printer, 1964). Although little organic material survived at this eroded site, diagnostic pottery and stone tools were recovered from a protected and homogeneous occupation layer. This provided one of the few culturally pure sites of Early Woodland nature in the north-east. While some quantitative analysis of the material has been attempted here, the materials thereby available would have been of greater value had the analysis been more comprehensive and the illustrations of artefacts more legible.

\section{Index to Publications of the Bureau of American Ethnology}

The Bureau of American Ethnology has published an index to the first 100 numbers of its Bulletin, which is likely to be of immense va'ue, even though the Bulletins are now well advanced in their second century (Bulletin No. 178: Index to Bulletins 1-100 of the Bureau of American Ethnology, with Index to Contributions to N. American Ethnology, Introductions and Miscellaneous Publications. By Biren Bonnerjea. Pp. vi +726 . Washington. D.C.: Government Printing Office, 1963. 3.50 dollars). In addition to the subject index, there are separate indexes of authors and titles, and of illustrations. For good measure, indexes of the ethnological material in three other series which are largely out of print are added, namely, Contributions to North American Ethnology, Introductions, and Miscellaneous Publications.

\section{University News :}

Leeds

Dr. G. W. JoHnson has been appointed lecturer in the Department of Metallurgy. Mrs. J. Tough has been appointed lecturer in the Institute of Education.

London

THe following titles have been conferred: professor of metallurgical chemistry, on Dr. C. B. Alcock, in respect of his post at the Imperial College of Science and Technology; professor of rural economy, on Dr. G. P. Wibberley, in respect of his post at Wye College; professor of histology, on Dr. F. R. Johnson, in respect of his post at the London Hospital Medical College; professor of embryology, on Dr. P. H. Spencer-Silver, in respect of his post at the Middlesex Hospital Medical School; reader in biophysics, on Mr. D. K. Hill, in respect of his post at the Postgraduate Medical School of London; reader in hæmatology, on Mr. J. G. Humble, in respect of his post at Westminster Medical School; reader in psychology, on Dr. R. J. Audley, in respect of his post at University College.

Sheffield

Prof. R. S. WAters, professor of geography in the University of Canterbury, New Zealand, has been appointed to a chair of geology.

\section{Battersea College of Technology}

Battersea College of Technology, in anticipation of the granting of university status, has conferred the title of professor on the following heads of departments: Dr. F. M. Arscott (mathematics); Dr. L. R. B. Elton (physics); Dr. V. S. Griffiths (spectroscopy and chemical physics); Dr. Z. S. Makowski (eivil engineering); Dr. J. E. Salmon (chemistry); Dr. S. R. Tailby (chemical engineering). A petition is in preparation for presentation to H.M. The Queen in Council for a royal charter incorporating the University, which it is hoped may be entitled the University of Surrey.

\section{The International Institute for Conservation of Historic} and Artistic Works

AT the annual general meeting of the International Institute for Conservation of Historic and Artistic Works the following officers were elected: President, Dr. A. van Schendel; Vice-President, Mr. N. Brommelle; SecretaryGeneral, Mr. N. Reid. Mr. F. I. G. Rawlins, the first secretary-general of the Institute and vice-president, was elected an Honorary Fellow of the Institute.

\section{Announcements}

THE Elwell Award papers for 1964 will be presented at an ordinary meeting of the Midlands Section of the Society for Analytical Chemistry, which will be held in the University of Birmingham on September 16.

A. HALF-DAY meeting of the Thin-Layer Chromatography Group of the Society for Analytical Chemistry will be held in Nottingham on September 23. Further information can be obtained from the Society for A.na!ytical Chemistry, 14 Belgrave Square, London, S.W.1.

AN international conference on "The Earth Sciences" will be held at the Massachusetts Institute of Technology during September 30-October 2. Further information can be obtained from Dr. H. Gr. Houghton. Department of Meteorology, Massachusetts Institute of Technology, Cambridge 39, Massachusetts.

A. JOINT meeting of the Microchemical Methods Group and the Scottish Section of the Society for Analytical Chemistry on "Automatic Methods of Analysis" will be held in the University of Aberdeen during September 25-26. Further information can be obtained from the Society for Analytical Chemistry, 14 Belgrave Square, London, S.W.I.

The Australian Science Index, April 1964 (8, No. 4), contains a further 300 entries of articles published in Australian scientific and technical periodicals. The entries are classified under general; physical sciences, engineering, technology and biological sciences, agriculture; and there are subdivisions of sciences, etc. There is also an author index and a subject index.

A course of instruction in "Powder Technology", leading to a College postgraduate diploma, will be held in King's College, University of London, commencing in October, under the direction of Prof. H. E. Rose. The course, which will extend over one academic year, is designed for students having a first degree in engineering, physics, ehemistry or certain other approved branches of applied science. Further information can be obtained from A. Davies, King's College, Strand, London, W.C.2. The fee for the course will be $£ 87$.

Erratum. In the communication entitled "Ammonium Production in Soil under Waterlogged Conditions as an Indox of Nitrogen Availability", by S. A. Waring and Prof. J. M. Bremner, which appeared on p. 951 of the February 29 issue of Nature, it is stated in the twentyfirst line of the second paragraph that the standard sulphuric acid used was $0.0005 \mathrm{~N}$, whereas the correct figure is $0.005 \mathrm{~N}$. 